FOLIA POMERANAE UNIVERSITATIS TECHNOLOGIAE STETINENSIS

Folia Pomer. Univ. Technol. Stetin., Oeconomica 2017, 335(87)2, 193-204

Bożena NADOLNA, Marzena RYDZEWSKA-WŁODARCZYK

\title{
WYKORZYSTANIE METODY WebQuest NA ZAJĘCIACH Z ZAKRESU STRATEGII PODATKOWYCH
}

\section{USING THE WebQuest METHOD IN TEACHING OF TAXATION STRATEGY}

Zakład Ekonomii i Rachunkowości, Zachodniopomorski Uniwersytet Technologiczny w Szczecinie ul. Żołnierska 47, 71-210 Szczecin, e-mail: mrydzewska@zut.edu.pl, bnadolna@zut.edu.pl

\begin{abstract}
Summary. The aim of this article is to present a project on taxation strategies using the WebQuest method. The first part of the paper presents the essence of the WebQuest method. Then we discussed the possibilities of using it while studying at an economics college. In this section, also examples of topics carried out using the WebqQuest methodology within disciplines of sciences and subjects of study. Most often, this method is used when implementing the program of selected project activities. For the purposes of this article, a taxation strategies project has been prepared using this method. The procedure for a specific project using the WebQuest method is found at the end of the article.
\end{abstract}

Słowa kluczowe: WebQuest, metoda dydaktyczna, praca projektowa.

Key words: project work, teaching method, WebQuest.

\section{WSTĘP}

Kształcenie w warunkach dynamicznego rozwoju świata wymaga uzyskania przez młodych ludzi licznych kompetencji. Współcześnie w każdym systemie nauczania powinno się dążyć do kształcenia postaw i nawyków uczenia się przez całe życie, ciągłego pozyskiwania nowej wiedzy, nabywania umiejętności współpracy z innymi, przygotowywania do rozwiązywania problemów oraz wykorzystywania zasobów informatycznych. Dotyczy to również kształcenia na uczelni. Szczególną formą zajęć rozwijającą powyższe kompetencje są zajęcia projektowe. W ich ramach można kształtować umiejętność zdobywania wiedzy i umiejętności praktyczne wymagane w pracy zawodowej, przy wykorzystaniu różnych narzędzi dydaktycznych. Jednym $z$ nich jest metoda WebQuest (WQ). Polega ona na wykorzystywaniu technologii informacyjno-komunikacyjnych w procesie dydaktycznym. Twórcy tej metody ${ }^{1}$ i nauczyciele wskazują, że pozwala ona studentom pracować w ich własnym tempie, rozwija twórcze myślenie, stymuluje aktywność i współpracę grupową, ukierunkowuje pracę badawczą oraz wspiera omawiane treści dodatkowymi informacjami.

Celem artykułu jest przedstawienie projektu z zakresu strategii podatkowych przy wykorzystaniu metody WebQuest.

W początkowej części artykułu przedstawiono istotę metody Webquest. Następnie zostały omówione możliwości jej wykorzystania podczas zajęć na uczelni ekonomicznej. W tej części

\footnotetext{
${ }^{1}$ Przyjmuje się, że twórcą WQ jest dr Bernard J. Dodge, profesor Uniwersytetu w San Diego w USA.
} 
artykułu zostały sformułowanie również przykładowe tematy realizowane przy wykorzystaniu WQ w ramach poszczególnych dyscyplin naukowych i prowadzonych przedmiotów. Metodę tę wykorzystuje się podczas realizacji programu nauczania wybranych zajęć projektowych.

\section{MATERIAŁ I METODY}

$\mathrm{Na}$ potrzeby artykułu został przygotowany projekt przy wykorzystaniu WQ na zajęcia $z$ przedmiotu strategie podatkowe. Program nauczania tego przedmiotu zostanie przedstawiony w trzeciej części artykułu, a procedura konkretnego projektu z wykorzystaniem metody WQ w końcowej części artykułu.

W części teoretycznej zastosowano metody analizy i krytyki źródeł odnoszących się do istoty i wykorzystania metody WebQuest w nauczaniu. W części koncepcyjnej pracy do opracowania przykładu zajęć projektowych z zakresu strategii podatkowych z zastosowaniem metody WQ użyto podejścia dedukcyjnego.

\section{ISTOTA I PROCEDURY TECHNIKI WebQuest}

Do najważniejszych zadań współczesnej edukacji należy:

1) kształcenie u osób uczących się umiejętności krytycznej oceny, selekcji, porządkowania oraz przekształcania informacji w wiedzę i umiejętności jej zaprezentowania;

2) budowanie intelektualnych modeli rzeczywistości, które czynią informację użyteczną;

3) wyposażenie uczniów w wiedzę i odpowiedni system wartości;

4) przygotowanie osób uczących się do przekształcania informacji w wiedzę, a w konsekwencji w mądrość;

5) uczenie kreatywności oraz umiejętności tworzenia oryginalnej wiedzy i metod rozwiązywania problemów.

$\mathrm{Na}$ tej podstawie wykształciła się metoda WebQuest. Jej początki datuje się na lata dziewięćdziesiąte XX wieku, gdy usługi internetowe i wykorzystanie stron WWW dopiero zaczynały się upowszechniać. WQ stała się innowacyjną metodą budowy wiedzy opartej na samodzielnym poszukiwaniu, porządkowaniu i selekcjonowaniu informacji, pochodzących z założenia z internetu (Szafraniec, http://www.womkat.edu.pl/files/standaryzacja/ Materialydydaktyczne). WQ można zdefiniować jako swoistą działalność badawczą, w której większość lub wszystkie informacje wykorzystane przez badacza pochodzą z internetu, przy czym metoda ta jest tak zaprojektowana, aby motywować do twórczego wykorzystania informacji, a nie tylko ich wyszukania w internecie oraz aby wspomagać myślenie na poziomie analizy, syntezy i ewaluacji informacji (Dodge 1995; Szafraniec, http://www.womkat.edu.pl/files/standaryzacja/ Materialydydaktyczne). W odniesieniu do nauczania WQ można uznać jako metodę budowania przez uczących się własnej wiedzy przez doświadczenie. Jest to zatem metoda nauczania oparta na teorii konstruktywizmu². Nauczanie z wykorzystaniem WQ jest nakierowane na wyszukiwanie przez uczących się informacji z dostępnych zasobów internetowych, na ich

\footnotetext{
2 Zgodnie z teorią konstruktywizmu ludzie, ucząc się w interakcji z otoczeniem, aktywnie konstruują swoją wiedzę, wykorzystując już posiadane jej zasoby. Nauka polega zatem nie na rejestrowaniu wiedzy, ale na budowie z dostępnych informacji struktury wiedzy (Resnick i Klopfer 1989). Konstruktywizm wskazuje zatem na proces tworzenia i rozwijania swojej wiedzy (Dylak, http://www.cen.uni.wroc.pl/teksty/konstrukcja.pdf).
} 
krytycznej analizie, przetwarzaniu i tworzeniu nowej wiedzy. Ponieważ informacje używane w trakcie uczenia się i rozwiązywania problemów badawczych są pozyskiwane w wyniku własnej aktywności oraz w sposób interaktywny, metodę tę zalicza się do grupy metod aktywnych (Dylak, http://www.cen.uni.wroc.pl/teksty/konstrukcja.pdf; Lubina, http://www.e-mentor.edu.pl/drukuj/artykul/numer/8/id/111; Jarosz 2002). WQ kształtuje jednocześnie umiejętności badawcze, zarządzania czasem, organizowania pracy własnej, umiejętności prezentowania efektów swojej pracy. Zawiera ponadto elementy uczenia się zespołowego (współpracy w zespole, komunikacji, zarządzania zespołem). Można też stwierdzić, że WQ wykorzystuje zasoby internetu w sposób innowacyjny i że opcjonalnie jest uzupełniana innymi materiałami dydaktycznymi. Z przedstawionych rozważań wynika, że celem metody WebQuestu jest rozwinięcie u uczniów umiejętności problemowego, krytycznego i twórczego myślenia oraz współpracy w zespole (Polak 2014).

Z uwagi na zakres tematyczny metoda WQ może mieć zastosowanie do jednej dziedziny nauki / przedmiotu lub może mieć charakter interdyscyplinarny (ścieżki międzyprzedmiotowe). Ze względu na czas realizacji (wykonania zadania, rozwiązania problemu) WQ może być używana:

- krótkoterminowo, co ma miejsce wówczas, gdy celem jej zastosowania jest zdobycie przez osoby uczące się nowej wiedzy; uczący się poszukują i opracowują poszczególne informacje oraz udostępniają je innym, np. za pomocą stron WWW;

- długoterminowo, gdy uczący się, wykorzystując internet, poszerzają wiedzę zdobytą w inny sposób; dzięki WQ uczący się pracują samodzielnie, tworzą hipotezy, analizują informacje, oceniają je, łączą z dotychczasową wiedzą i prezentują w określonej formie.

Proces tworzenia WebQuest wymaga:

1) zidentyfikowania tematu związanego $z$ dostępnymi zasobami internetowymi;

2) uporządkowania, skategoryzowania i pogrupowania uzyskanej wiedzy, materiałów i innych zasobów w formie:

- stron WWW i baz danych (zasoby online);

- podręcznych materiałów i projektów (zasoby offline);

- zasobów ludzkich (eksperci online i lokalni eksperci);

3) opracowania konspektu.

Postawienie i rozwiązanie problemu z zastosowaniem metody WQ przebiega według określonej procedury, która stanowi schemat postępowania zbudowany z zestawu elementów (ogniw); tworzą je:

1) temat $W Q$,

2) wprowadzenie,

3) zadanie,

4) proces,

5) źródła,

6) ewaluacja,

7) konkluzja - podsumowanie.

Temat WQ powinien wskazywać problem do rozwiązania, a przy tym powinien zaciekawić osoby uczące się, zainspirować i zachęcić je do działania. Z kolei wprowadzenie do zadania wymaga od nauczyciela / mentora: 
a) przedstawienia głównego problemu;

b) sformułowania celów i spodziewanych efektów;

c) dostarczenia niezbędnych informacji kontekstowych dotyczących tła i uwarunkowań badanego problemu w taki sposób, aby aktywować u uczących się różne sposoby myślenia;

d) zmotywowania uczących się do działania.

Treść merytoryczną, a jednocześnie najważniejszą część metody WQ stanowi zadanie lub grupa zadań problemowych (Furgoł i Hojnacki, https://edustore.eu/publikacje-edukacyjne/30-metoda-webquest). Nauczyciel, przedstawiając uczącym się treść zadania, wyjaśnia, co i w jakiej formie powinni wykonać oraz omawia znaczenie ich aktywności. Zadanie powinno:

a) być interesujące i wykonalne,

b) opisywać potrzebne narzędzia i aktywności uczących się,

c) wskazywać na formę, w jakiej powinno być przedstawione rozwiązanie, na przykład jako pisemny raport, prezentacja multimedialna lub inna, na przykład jako inscenizacja czy przemówienie.

Zadanie lub zadania składające się na WQ muszą być zatem przekazane w formie wymagającej od uczących się aktywności typu:

- rozwiąż zagadkę,

- opisz problem,

- zaprojektuj,

- przeanalizuj strukturę,

- zbierz opinie na temat i porównaj je z własnymi przemyśleniami,

- znajdź dowody popierające ideę.

Powinny to być aktywności, które będą wymuszały na uczestniku wyszukanie informacji w sieci, ich przeanalizowanie i przygotowanie podsumowania w formie:

- eseju;

- sprawozdania, raportu z badań;

- zestawienia danych;

- zadania twórczego;

- zadania dziennikarskiego;

- projektu, posteru, plakatu, planu;

- wystąpienia (apelu, przemówienia, głosu w dyskusji).

Ważnym elementem WQ jest proces, czyli opis procesu pozyskiwania informacji. Obejmuje on opis wszystkich aspektów organizacyjnych przedsięwzięcia, takich jak sposób i miejsce pracy, czas realizacji, podział na etapy, podział na grupy, zasady przydziału ról i zadań w grupach, sposób prezentacji efektów. Opracowanie procedury rozwiązania problemu, czyli wskazanie kolejnych kroków, które pozwolą uczącym się zrealizować zadanie zgodnie z wytyczoną ścieżką, wymaga:

a) podziału zadania głównego na zadania cząstkowe,

b) określenia zasad podziału ról i zadań dla poszczególnych członków zespołu,

c) opisania ról do odegrania przez uczących się,

d) określenia produktu końcowego. 
Warto podkreślić, że WebQuest może zawierać dodatkowe pomoce dydaktyczne dla rozwiązujących zadanie w formie: przewodników z pytaniami pomocniczymi i wskazówkami, map mentalnych, harmonogramów działań, diagramów przyczynowo-skutkowych.

Zadania dydaktyczne, realizowane z użyciem metody WebQuest, powinny zawierać listę źródeł informacji pozwalających uczącym się wykonać zadanie / rozwiązać problem; mogą one mieć postać:

1) źródeł sieciowych - listy stron WWW i internetowych baz danych, internetowe metody komunikacji interaktywnej z ludźmi - ekspertami, świadkami etc., takie jak fora, e-mail (zasoby online);

2) źródeł i zasobów informatycznych offline - zalecane lub wymagane oprogramowanie używane w trakcie realizacji, dane na dyskach, np. filmy wideo, bazy danych, w tym zbiorów bibliotecznych;

3) źródeł multimedialnych - zalecane filmy, materiały wideo i dźwiękowe;

4) źródeł książkowych - książki, periodyki, roczniki statystyczne, dokumenty źródłowe;

5) innych źródeł, w tym zasobów ludzkich - nauczyciele, eksperci.

Należy podkreślić, że w zależności od zadania / problemu podczas jego rozwiązywania uczący się mogą wykorzystywać jedno źródło lub wiele źródeł informacji.

Bardzo ważnym elementem WQ jest ewaluacja, która wskazuje sposób oceny rozwiązania zadania. Przedmiotem pomiaru są zarówno osiągnięcia uczących się, jak i zaangażowanie. Ewaluacja pozwala wartościować efekty uczenia się powstałe w wyniku realizacji zadania oraz ustalić ocenę końcową. Wymaga to, przede wszystkim, ustalenia obszarów, które będą podlegały ocenie i przypisania im kryteriów oceny. W tym celu należy przeanalizować wszystkie aktywności / czynności, jakie będą wykonywali uczący się podczas realizacji zadania, wskazać kluczowe ich elementy, a następnie przypisać im kryteria oceny.

W zależności od rodzaju zadania ocena WQ obejmuje kilka (4-8) obszarów. Każdemu z nich należy przypisać opisowe i / lub punktowe oceny. Dla każdego ocenianego obszaru należy ustalić i nazwać kolejne poziomy wykonania zadania, np. poziom pierwszy, poziom drugi i poziom trzeci lub początkujący, średnio zaawansowany i zaawansowany albo dostateczny, dobry, bardzo dobry, a następnie przypisać im określoną liczbę punktów. Podczas ewaluacji zadania powinna być przeprowadzona analiza poszczególnych obszarów i ich operacjonalizacja, tj. określenie, jakie elementy zadania i na jakim poziomie zostały wykonane przez początkujących, średnio zaawansowanych itd. Na koniec należy przyporządkować określonym liczbom punktów oceny (oceny szkolne i / lub w formie ECTS). Do przeprowadzenia ewaluacji rozwiązania można wykorzystać tabelę ewaluacyjną (tab. 1).

Tabela 1. Wzór tabeli ewaluacyjnej

\begin{tabular}{|l|l|l|l|}
\hline \multirow{2}{*}{ Obszar ewaluacji } & \multicolumn{3}{|c|}{ Poziom wykonania } \\
\cline { 2 - 4 } & początkujący & średnio zaawansowany & zaawansowany \\
\hline Obszar 1 & & & \\
\hline Obszar 2 & & & \\
\hline Obszar 3 & & & \\
\hline Obszar 4 & & & \\
\hline
\end{tabular}


Ocenie powinna podlegać zarówno treść stanowiąca rozwiązanie problemu, jak i sposób wykonania zadania. Kryteria ewaluacyjne różnić się będą w zależności od rodzaju zadania i sposobu prezentacji rozwiązania. W wypadku prezentacji ustnej ocenie powinny podlegać: organizacja wypowiedzi, treść wypowiedzi oraz sposób prezentacji treści - gramatyka i wymowa oraz komunikacja niewerbalna. Jeżeli rozwiązanie zadania będzie przedstawione w formie apelu, to oceniane powinny być w szczególności: jakość argumentów, reakcje „publiczności” i organizacja dyskusji. Z kolei, gdy rozwiązanie problemu jest prezentowane w formie prezentacji multimedialnej, oceniane powinny być: aspekty techniczne, estetyka wykonania, stylistyka i przejrzystość prezentacji. Gdy natomiast rozwiązaniem zadania jest praca pisemna, kryteria ewaluacji powinny obejmować: poziom merytoryczny, kompozycję, jakość języka i edycję (formatowanie) tekstu.

W wypadku prac plastycznych ocenie podlegają z reguły:

1) technika wykonania;

2) nowatorstwo, oryginalność formy;

3) kolorystyka;

4) przekaz artystyczny;

5) wrażenia estetyczne.

Ocena współpracy podczas wykonywania zadania powinna uwzględniać:

1) wzajemną pomoc,

2) odpowiedzialne działanie,

3) sposób rozwiązywania konfliktów.

Z kolei jeżeli zadanie polega na opracowaniu projektu (pracy projektowej), to kryteria ewaluacji stanowią zwykle:

1) kreatywność,

2) wymiar praktyczny projektu (zastosowanie),

3) uzasadnienie wyboru danego rozwiązania.

WebQuest zamyka konkluzja. Na tym etapie następuje podsumowanie zadania. Nauczyciel przypomina uczącym to, czego się nauczyli i zachęca do rozszerzenia tego typu doświadczeń na inne obszary wiedzy. Podsumowanie powinno stanowić przyczynek do refleksji na temat zastosowanej procedury i ewentualnych jej modyfikacji; może też być podstawą dyskusji w gronie uczących się.

\section{ZAKRES ZASTOSOWANIA METODY WebQuest W KSZTAŁCENIU NA STUDIACH EKONOMICZNYCH}

Metoda WebQuest może być stosowana we wszystkich formach nauczania na studiach ekonomicznych. Można ją wykorzystywać zarówno w kształceniu stacjonarnym, niestacjonarnym, jak i w e-learingu. Jak już wspomniano, najbardziej przydatna jest ona podczas zajęć projektowych realizowanych na każdej uczelni. Uczelnie ekonomiczne zazwyczaj prowadzą zajęcia dydaktyczne w ramach trzech dyscyplin naukowych, takich jak: nauki o zarządzaniu, ekonomia i finanse ${ }^{3}$, a w ich ramach są realizowane zajęcia $z$ określonych przedmiotów. W części lub całości każdego z tych przedmiotów mogą być realizowane projekty z wykorzystaniem metody WebQuest. Przykładowe tematy projektów w ramach wybranych przedmiotów w poszczególnych dyscyplinach zostały przedstawione w tab. 2.

\footnotetext{
${ }^{3} \mathrm{~W}$ skład nauk ekonomicznych wchodzi jeszcze towaroznawstwo.
} 
Tabela 2. Wybrane projekty w ramach poszczególnych przedmiotów, realizowane za pomocą metody WebQuest

\begin{tabular}{|c|c|c|}
\hline $\begin{array}{l}\text { Dyscyplina } \\
\text { naukowa }\end{array}$ & Przedmioty & Projekty \\
\hline \multirow{3}{*}{$\begin{array}{l}\text { Nauki } \\
\text { o zarządzaniu }\end{array}$} & marketing & $\begin{array}{l}\text { 1. Wady i zalety reklamy } \\
\text { 2. Problemy zakupów przez internet } \\
\text { 3. Współczesny konsument i jego prawa }\end{array}$ \\
\hline & $\begin{array}{l}\text { zarządzanie zasobami } \\
\text { ludzkimi }\end{array}$ & $\begin{array}{l}\text { 1. Rozwiązywanie konfliktów interpersonalnych i grupowych } \\
\text { 2. Sposoby rekrutowania ludzi do pracy } \\
\text { 3. Wykorzystanie systemów wynagradzania do kształtowania motywacji }\end{array}$ \\
\hline & $\begin{array}{l}\text { zarządzanie } \\
\text { przedsiębiorstwami }\end{array}$ & $\begin{array}{l}\text { 1. Strategia przedsiębiorstwa - czy jest konieczna? } \\
\text { 2. Projektowanie stanowisk pracy w organizacji } \\
\text { 3. Zarządzanie kulturową różnorodnością w organizacji }\end{array}$ \\
\hline \multirow{4}{*}{ Ekonomia } & ekonomia społeczna & $\begin{array}{l}\text { 1. Społeczna odpowiedzialność biznesu i dokonania } \\
\text { 2. Państwo a społeczna odpowiedzialność } \\
\text { 3. Determinanty rozwoju ekonomii społecznej }\end{array}$ \\
\hline & makroekonomia & $\begin{array}{l}\text { 1. Własność a efektywność } \\
\text { 2. Przyczyny kryzysów gospodarczych } \\
\text { 3. Korzyści z handlu międzynarodowego }\end{array}$ \\
\hline & mikroekonomia & $\begin{array}{l}\text { 1. Dlaczego powstają monopole } \\
\text { 2. Użyteczność w ujęciu ekonomicznym } \\
\text { 3. Robinson i Piętaszek a ekonomia dobrobytu }\end{array}$ \\
\hline & $\begin{array}{l}\text { historia myśli } \\
\text { ekonomicznej }\end{array}$ & $\begin{array}{l}\text { 1. Korzyści ze studiowania historii myśli ekonomicznej } \\
\text { 2. Analiza kapitalizmu według Veblena - czy się z nią zgadzasz? } \\
\text { 3. Filozoficzne podejście Keynesa do polityki a jego przeciwnicy }\end{array}$ \\
\hline \multirow{4}{*}{ Finanse } & finanse przedsiębiorstw & $\begin{array}{l}\text { 1. Rozliczenia międzynarodowe i ich wpływ na gospodarkę finan- } \\
\text { sową przedsiębiorstw } \\
\text { 2. Wpływ polityki monetarnej i fiskalnej na sytuację finansową } \\
\text { przedsiębiorstwa } \\
\text { 3. Restrukturyzacja finansowa przedsiębiorstwa - konieczność czy } \\
\text { fanaberia }\end{array}$ \\
\hline & finanse publiczne & $\begin{array}{l}\text { 1. 1.Budżet państwa w warunkach kryzysu } \\
\text { 2. Finansowanie działalności sektora publicznego przez sektor } \\
\text { prywatny - przymus czy filantropia? } \\
\text { 3. W jakim celu wprowadza się podatki? Uzasadnij ich różnorod- } \\
\text { ność }\end{array}$ \\
\hline & $\begin{array}{l}\text { rachunkowość } \\
\text { zarządcza }\end{array}$ & $\begin{array}{l}\text { 1. Koszty w ujęciu rachunkowości i ekonomii } \\
\text { 2. Decyzje inwestycyjne - trudności i wezwania } \\
\text { 3. Czy krótkookresowe rachunki decyzyjne są potrzebne? }\end{array}$ \\
\hline & $\begin{array}{l}\text { rachunkowość } \\
\text { finansowa }\end{array}$ & $\begin{array}{l}\text { 1. Sprawozdanie finansowe - potrzebne czy niepotrzebne? } \\
\text { 2. Dlaczego rachunkowość jest trudna? } \\
\text { 3. Wpływ zasad rachunkowości na wycenę aktywów i pasywów } \\
\text { oraz elementów kształtujących wynik finansowy }\end{array}$ \\
\hline
\end{tabular}

Wybór tematu projektowego i jego sformułowanie jest niezmiernie ważne w procedurze tworzenia WQ. Punktem wyjścia przy określaniu tematu powinna być właściwa identyfikacja jego odbiorców, analiza dotychczasowego poziomu ich wiedzy merytorycznej i nabytych do tej pory umiejętności, np. w zakresie obsługi komputerów i znajomości oprogramowania. Właściwie sformułowany temat powinien być poprzedzony przedstawieniem uwarunkowań problemu, który ma być rozwiązany za pomocą techniki WQ. Sposób sformułowania tematu powinien być zrozumiały i interesujący dla studentów, powinien ich zaciekawić i zmotywować do poszukiwania odpowiedzi na pytania badawcze.

\section{PROGRAM PRZEDMIOTU STRATEGIE PODATKOWE}

Zajęcia w ramach przedmiotu strategie podatkowe mogą być realizowane na studiach pierwszego lub drugiego stopnia na kierunkach ekonomia, zarządzanie, finanse i rachunkowość lub podobnych oraz na tematycznych studiach podyplomowych. Zajęcia powinny być 
prowadzone w formie projektowej, w salach laboratoryjnych, w wymiarze minimum 30 godzin. Celem tych zajęć jest: poznanie istoty strategii podatkowych i warunków ich stosowania przez osoby (podmioty) prowadzące działalność gospodarczą, a także nabycie umiejętności doboru i wykorzystania instrumentów optymalizacji obciążeń podatkowych, z uwzględnieniem możliwości ich zastosowania, a także nabycie umiejętności opracowania strategii optymalizowania obciążeń podatkowych i monitorowania jej realizacji. Treści programowe przedmiotu w ujęciu syntetycznym przedstawia tab. 3 .

Tabela 3. Treści programowe przedmiotu strategie podatkowe

\begin{tabular}{|c|c|}
\hline Zagadnienie główne & Treść zajęć \\
\hline $\begin{array}{l}\text { Istota i elementy strate- } \\
\text { gii podatkowych }\end{array}$ & $\begin{array}{l}\text { 1. Pojęcie strategii podatkowych przedsiębiorstw } \\
\text { 2. Zakres przedmiotowy strategii podatkowych } \\
\text { 3. Zasady formułowania strategii podatkowych } \\
\text { 4. Opracowanie i wdrożenie strategii podatkowej przedsiębiorstwa } \\
\text { 5. Monitorowanie realizacji strategii podatkowej } \\
\text { 6. Oszustwa i nadużycia podatkowe a strategia podatkowa }\end{array}$ \\
\hline $\begin{array}{l}\text { Strategie podatkowe przed- } \\
\text { siębiorstw w zakresie po- } \\
\text { datku dochodowego }\end{array}$ & $\begin{array}{l}\text { 1. Dobór optymalnej formy podatku dochodowego } \\
\text { 2. Opodatkowanie podatkiem dochodowym a formy organizacyjno-prawne przedsię- } \\
\text { biorstw i wybór miejsca prowadzenia działalności } \\
\text { 3. Sposoby (instrumenty) optymalizacji rozliczeń podatkowych: } \\
\text { - amortyzacja jako instrument optymalizacji podatkowej } \\
\text { - } \text { kształtowanie momentu rozpoznania przychodów i kosztów } \\
\text { - } \text { rozliczanie kosztów bezpośrednich i pośrednich } \\
\text { - } \text { koszty usług marketingowych w kontekście minimalizacji zobowiązań podatkowych } \\
\text { - polityka płacowa przedsiębiorstwa w aspekcie optymalizacji obciążeń podatkowych } \\
\text { - zarządzanie wierzytelnościami } \\
\text { - zarządzanie stratą podatkową } \\
\text { - polityka prowadzenia ewidencji i rozliczeń a ciężar podatkowy } \\
\text { - } \text { wybór roku podatkowego i uproszczone zaliczki na podatek dochodowy }\end{array}$ \\
\hline $\begin{array}{l}\text { Obniżanie obciążeń fiskal- } \\
\text { nych w zakresie podat- } \\
\text { ków pośrednich }\end{array}$ & $\begin{array}{l}\text { 1. Podatki pośrednie a warunki optymalizacji obciążeń podatkowych przedsiębiorców } \\
\text { 2. Strategie podatkowe przedsiębiorstw w zakresie podatków pośrednich } \\
\text { 3. Metody i techniki obniżania obciążeń fiskalnych w zakresie podatku od towarów } \\
\text { i usług }\end{array}$ \\
\hline $\begin{array}{l}\text { Inne sposoby i narzędzia } \\
\text { optymalizacji podatkowej }\end{array}$ & $\begin{array}{l}\text { 1. Opodatkowanie a decyzje finansowe oraz płynność finansowa } \\
\text { 2. Podatkowa grupa kapitałowa } \\
\text { 3. Prowadzenie działalności w specjalnych strefach ekonomicznych } \\
\text { 4. Rezydencja podatkowa }\end{array}$ \\
\hline
\end{tabular}

Przedstawione w tab. 3 treści programowe są zaczerpnięte $z$ autorskiej propozycji sylabusa przygotowanego na potrzeby nowelizacji programu studiów realizowanego na Wydziale Ekonomicznym Zachodniopomorskiego Uniwersytetu Technologicznego w Szczecinie.

\section{PROJEKT ZADANIA REALIZOWANEGO PRZY WYKORZYSTANIU METODY WebQuest}

Jak już wspominano, zastosowanie metody WebQuest w procesie nauczania ma na celu zwiększanie efektywności kształcenia. Efektywność tę nauczyciel może uzyskać tylko w warunkach właściwego przygotowania całej procedury, z uwzględnieniem języka zrozumiałego dla studentów (tab. 4). 
Tabela 4. Projekt „Wybierz sposób opodatkowania dochodów twojej firmy ABC”, realizowany w ramach przedmiotu strategie podatkowe

\begin{tabular}{|c|c|c|}
\hline Lp. & $\begin{array}{c}\text { Element } \\
\text { procedury WQ }\end{array}$ & Opis realizacji \\
\hline 1 & Temat WQ & Wybierz sposób opodatkowania dochodów twojej firmy ABC \\
\hline 2 & Wprowadzenie & $\begin{array}{l}\text { Przed wami kolejny etap prac związanych z nabywaniem umiejętności wyboru formy } \\
\text { opodatkowania dochodów osób fizycznych prowadzących działalność gospodarczą. } \\
\text { W ramach tematu „Optymalizacja obciążeń w podatku dochodowym osób fizycznych } \\
\text { prowadzących działalność gospodarczą” musicie poznać i utrwalić wiadomości } \\
\text { dotyczące opodatkowania dochodów osób fizycznych w Polsce, a także nabyć } \\
\text { umiejętności dokonywania wyboru najkorzystniejszej formy podatku dochodowego. } \\
\text { Umiejętność „poruszania się” po tych przepisach jest dla was kluczową kompetencją, } \\
\text { która jest oczekiwana przez pracodawców od absolwentów waszego kierunku studiów. } \\
\text { Wiedzę z zakresu optymalizacji podatkowych wykorzystacie także na zajęciach } \\
\text { z zakresu ewidencji podatkowych }\end{array}$ \\
\hline 3 & Zadania & $\begin{array}{l}\text { Waszym zadaniem będzie wyszukanie, zebranie i opracowanie informacji o } 3 \text { pod- } \\
\text { stawowych formach opodatkowania dochodów osób fizycznych prowadzących } \\
\text { działalność gospodarczą w Polsce, czyli informacje o: } \\
\text { - podatku dochodowym od osób fizycznych płaconym na zasadach ogólnych - PIT } \\
\text { - zryczałtowanym podatku dochodowym od niektórych przychodów osiąganych } \\
\text { przez osoby fizyczne w formie ryczałtu od przychodów ewidencjonowanych - } \\
\text { ryczałt ewidencjonowany } \\
\text { - zryczałtowanym podatku dochodowym od niektórych przychodów osiąganych } \\
\text { przez osoby fizyczne w formie karty podatkowej } \\
\text { Dla wybranej firmy obliczycie wartość podatku dla każdej z możliwych form } \\
\text { opodatkowania i dokonacie wyboru najkorzystniejszej z punktu widzenia obciążenia } \\
\text { podatkowego. Na podstawie zebranych informacji przygotujecie prezentację mul- } \\
\text { timedialną sporządzoną w MS PowerPoint oraz poprowadzicie zajęcia warsztatowe } \\
\text { dla całej grupy. } \\
\text { Pracę wykonacie w } 3 \text { zespołach (podzielicie się na } 3 \text { zespoły). W każdym zespole } \\
\text { wybierzecie jednego lidera, który będzie koordynował waszą pracę oraz poprowadzi } \\
\text { zajęcia warsztatowe. Lider podzieli pomiędzy was obowiązki tematy do opracowania }\end{array}$ \\
\hline 4 & Proces & $\begin{array}{l}\text { 1. Podzielcie się na } 3 \text { zespoły } \\
\text { 2. Każdy zespół opracuje materiały dotyczące optymalizacji obciążenia podatkowego } \\
\text { w podatku dochodowym dla swojej firmy } \\
\text { 3. Wybierzcie w zespole lidera, który będzie koordynował waszą pracę oraz w efekcie } \\
\text { końcowym poprowadzi zajęci warsztatowe dla całej grupy } \\
\text { 4. Podzielcie się pracą } \\
\text { 5. Wasze materiały powinny zawierać następujące informacje: } \\
\text { - charakterystykę firmy (przedmiot i zakres działalności, informacje nt. zatrud- } \\
\text { nienia i jej majątku) } \\
\text { - przedmiot i podmiot opodatkowania firmy } \\
\text { - sposób obliczania podatku dla każdej z możliwych form opodatkowania } \\
\text { dochodów / przychodów waszej firmy } \\
\text { - podstawowe deklaracje podatkowe i ich charakterystyka dla każdej z możliwych } \\
\text { form opodatkowania } \\
\text { - symulację obciążeń podatkowych firmy } \\
\text { - wybór najkorzystniejszej formy opodatkowania podatkiem dochodowym wraz } \\
\text { z. Po zebraniu materiałów należy sporządzić scenariusz zajęć warsztatowych oraz, } \\
\text { jako pomoc dydaktyczną, prezentację multimedialną w MS PowerPoint } \\
\text { 7. Prezentacja w MS PowerPoint powinna być interesująca, efektowna i przejrzysta. } \\
\text { Oprócz treści należy umieścić w niej elementy graficzne (np. wzory ewidencji, } \\
\text { deklaracji podatkowych). Należy pamiętać o oszczędnym stosowaniu efektów } \\
\text { animacji } \\
\text { 8. Na zajęciach należy przeprowadzić ze studentami zajęcia warsztatowe dotyczące } \\
\text { optymalizacji podatkowej } \\
\text { 9. Za wykonanie projektu cały zespół zostanie oceniony według kryteriów podanych } \\
\text { w tabeli ewaluacyjnej } \\
\text { 10. Lider grupy musi kontaktować się z nauczycielem w następujących momentach: } \\
\text { - po zebraniu wszystkich materiałów } \\
\text { - po sporządzeniu scenariusza zajęć } \\
\text { - po przygotowaniu prezentacji multimedialnej } \\
\text { 11. Czas pracy - dwa tygodnie } \\
\text { 12. Termin przeprowadzenia przez was warsztatów ustalimy indywidualnie }\end{array}$ \\
\hline
\end{tabular}


Tabela 4. Projekt „Wybierz sposób opodatkowania dochodów twojej firmy ABC”, realizowany w ramach przedmiotu strategie podatkowe (cd.)

\begin{tabular}{|c|c|c|c|c|c|c|c|}
\hline Lp. & $\begin{array}{c}\text { Element } \\
\text { procedury WQ }\end{array}$ & & & Opis realiza & & & \\
\hline 5 & Źródła & $\begin{array}{l}\text { Wybrane linki } \\
\text { - strona zawi } \\
\text { - strona Minis } \\
\text { - strona o po } \\
\text { - poradnik int } \\
\text { - portal finans } \\
\text { - baza aktów } \\
\text { - serwis inter } \\
\text { oraz } \\
\text { - wyszukiwar }\end{array}$ & $\begin{array}{l}\text { do stron zawiera } \\
\text { erająca wszystki } \\
\text { sterstwa Finansó } \\
\text { datku dochodow } \\
\text { ernetowy - poda } \\
\text { sowy - money.pl } \\
\text { prawnych - isap } \\
\text { netowy - http://h } \\
\text { ki internetowe, n }\end{array}$ & $\begin{array}{l}\text { ających informacje } \\
\text { ie informacje o pc } \\
\text { ów - mf.gov.pl } \\
\text { ym od osób fizyc } \\
\text { atki.egospodarka } \\
\text { p.sejm.gov.pl } \\
\text { www.gofin.pl/ } \\
\text { pp. Google.pl }\end{array}$ & $\begin{array}{l}\text { e, które przydad } \\
\text { odatkach w Pols } \\
\text { sznych (PIT) - pi } \\
\text { pl }\end{array}$ & $\begin{array}{l}\text { Izą się w pracy: } \\
\text { sce - podatki.pl } \\
\text { it.pl }\end{array}$ & \\
\hline \multirow{8}{*}{6} & \multirow{8}{*}{ Ewaluacja } & \multicolumn{6}{|c|}{$\begin{array}{l}\text { Teraz dowiesz się, jakie elementy w tym projekcie będą oceniane. Ocenie podlega } \\
\text { praca całego zespołu. Za projekt można otrzymać } 20 \text { punktów }\end{array}$} \\
\hline & & \multirow[b]{2}{*}{ Kryterium oceny } & \multicolumn{4}{|c|}{ Ocena } & \multirow[b]{2}{*}{ Punkty } \\
\hline & & & $\begin{array}{l}\text { niedostateczna } \\
\text { (2 punkty) }\end{array}$ & $\begin{array}{l}\text { podstawowa } \\
\text { (3 punkty) }\end{array}$ & $\begin{array}{c}\text { dopełniająca } \\
\text { (4 punkty) }\end{array}$ & $\begin{array}{c}\text { wykraczająca } \\
\text { (5 punkty) }\end{array}$ & \\
\hline & & $\begin{array}{l}\text { Właściwy dobór } \\
\text { i przetworzenie } \\
\text { informacji }\end{array}$ & $\begin{array}{l}\text { informacje ubogie, } \\
\text { nieuporządkowane }\end{array}$ & $\begin{array}{c}\text { informacje niepełne, } \\
\text { częściowo } \\
\text { uporządkowane }\end{array}$ & \begin{tabular}{|c|} 
informacje pełne, \\
uporządkowane, \\
ciekawe, zgodne z \\
aktualnie \\
obowiązującymi \\
przepisami prawa
\end{tabular} & $\begin{array}{c}\text { informacje } \\
\text { wyczerpujace, } \\
\text { bardzo ciekawe, } \\
\text { prawidłowo } \\
\text { uporządkowane, } \\
\text { zgodne z aktualnie } \\
\text { obowiazującymi } \\
\text { przepisami prawa } \\
\end{array}$ & $2-5$ \\
\hline & & $\begin{array}{l}\text { Atrakcyjność } \\
\text { prezentacji }\end{array}$ & $\begin{array}{c}\text { słaba estetyka, } \\
\text { nieodpowiednia } \\
\text { szata graficzna, zbyt } \\
\text { wiele animacji }\end{array}$ & $\begin{array}{c}\text { odpowiednia szata } \\
\text { graficzna, wysteppuja } \\
\text { elementy animacji }\end{array}$ & \begin{tabular}{|c|} 
ładna szata \\
graficzna, \\
poprawna \\
animacja, \\
występują elementy \\
graficzne \\
\end{tabular} & \begin{tabular}{|c} 
szata graficzna \\
prawidłowa w \\
zakresie wszystkich \\
elementów
\end{tabular} & $2-5$ \\
\hline & & $\begin{array}{l}\text { Sposób } \\
\text { przeprowadzenia } \\
\text { zajęć }\end{array}$ & $\begin{array}{c}\text { zajęcia nieciekawie } \\
\text { prowadzone, } \\
\text { prowadzacy czyta } \\
\text { z notatek, nie zna } \\
\text { prezentacji }\end{array}$ & \begin{tabular}{|} 
zajęcia prowadzone \\
poprawnie, ale \\
prowadzący musi \\
często zaglądać do \\
notatek i konspektu \\
prezentacji
\end{tabular} & \begin{tabular}{|c|} 
zajęcia prawidłowo \\
prowadzone, \\
ciekawie, ale \\
brakuje ćwiczeń \\
praktycznych - \\
mało przykładów
\end{tabular} & \begin{tabular}{|c|} 
zajęcia \\
poprowadzona \\
bardzo ciekawie, \\
prowadzący umie \\
zaciekawić \\
i zaktywizować \\
studentów, bardzo \\
ciekawe ćwiczenia \\
praktyczne \\
i przykłady \\
\end{tabular} & $2-5$ \\
\hline & & $\begin{array}{l}\text { Umiejętność } \\
\text { pracy w grupie }\end{array}$ & $\begin{array}{l}\text { brak współpracy } \\
\text { w grupie }\end{array}$ & \begin{tabular}{|c|} 
praca indywidualna, \\
zaangażowanie w \\
pracę wspólną \\
niewystarczające \\
\end{tabular} & $\begin{array}{c}\text { dobra organizacja } \\
\text { i współpraca } \\
\text { w grupie }\end{array}$ & $\begin{array}{c}\text { doskonała } \\
\text { organizacja } \\
\text { i współpraca } \\
\text { w grupie } \\
\end{array}$ & $2-5$ \\
\hline & & \multicolumn{6}{|c|}{$\begin{array}{l}\text { Skala ocen: } \\
20-17-\text { bardzo dobry } \\
16-13-\text { dobry } \\
12-9-\text { dostateczny } \\
8-0-\text { niedostateczny }\end{array}$} \\
\hline 7 & Konkluzja & \multicolumn{6}{|c|}{$\begin{array}{l}\text { Realizując projekt, mogliście samodzielnie powtórzyć i utrwalić wiadomości o naj- } \\
\text { ważniejszych podatkach w Polsce, a także poznać przesłanki i zasady opty- } \\
\text { malizowania opodatkowania dochodów osób fizycznych prowadzących działalność } \\
\text { gospodarczą. Wiecie już także, jak prowadzić zajęcia w grupie i jak trudno jest } \\
\text { zaktywizować studentów do pracy. Mam nadzieję, że wykonanie tego zadania } \\
\text { przyczyni się do waszego sukcesu w pracy zawodowej }\end{array}$} \\
\hline
\end{tabular}

W ramach przedmiotu strategie podatkowe większość zajęć można zrealizować przy wykorzystaniu metody WebQuest. W tradycyjnej formie podającej należałoby jednak omówić zagadnienia wprowadzające do przedmiotu i podsumowujące jego treści. 


\section{PODSUMOWANIE}

Współczesne kształcenie na poziomie wyższym powinno wyposażać studentów w wiedzę i odpowiedni system wartości. W zdobywaniu i wykorzystywaniu tej wiedzy powinni być oni kreatywni oraz powinni posiąść umiejętność swobodnego rozwiązywania problemów. Proponowana metoda nauczania WebQuest, bazując na teorii konstruktywizmu, motywuje studenta do uczenia i budowania własnej wiedzy w wyniku aktywności poprzez zdobywanie doświadczenia, przy wykorzystywaniu w sposób innowacyjny zasobów internetu, a także wzmacnia kompetencje społeczne w zakresie pracy w grupie, zarządzania czasem, etyki biznesu.

\section{PIŚMIENNICTWO}

Dodge B. 1997. Some thouhts about WebQuests. San Diego University, http://webquest.sdsu.edu/ labout_webquests, http://webquest.org/sdsu/about_webquests.html, dostęp: 20.09.2014.

Dylak S. Konstruktywizm jako obiecująca perspektywa kształcenia nauczycieli. Wrocław, Centrum Edukacji Nauczycielskiej, http://www.cen.uni.wroc.pl/teksty/konstrukcja.pdf, dostęp: 16.10.2016.

Furgoł S., Hojnacki L. Metoda Webquest. Poradnik dla nauczyciela. Wirtualna biblioteka nowoczesnego nauczyciela i ucznia. ePUB, https://edustore.eu/publikacje-edukacyjne/30-metoda-webquest, dostęp: 20.08.2016.

Jarosz B. 2002. Konstruktywizm - technologia informacyjna - zmiany w procesie kształcenia, w: Techniki komputerowe w przekazie edukacyjnym. Red. J. Morbitzer. Kraków, Wydaw. Nauk. Akad. Pedagog.

Lubina E. Konstruktywistyczne i behawioralne aspekty kształcenia zdalnego, http://www.e-mentor.edu.pl, dostęp: 16.10.2016.

Polak M. 2014. Wykorzystujmy szeroko webquesty w nauczaniu, http://www.edunews.pl/narzedzia-i-projekty, dostęp: 10.10.2016.

Resnick L.B., Klopfer L.E. 1989. Toward the thinking curriculum: Current cognitive research. Alexandria, VA: Association for Supervision and Curriculum Development Yearbook.

Szafraniec M. Innowacyjne metody kształcenia, http://www.womkat.edu.pl/files/standaryzacja/ Materialydydaktyczne, dostęp: 20.08.2016. 
